\title{
COVID-19 Crisis Transformative Impact on Job Execution and E-commerce
}

\author{
Cristian Bogdan Onete ${ }^{1}$, Sandra Diana Chița ${ }^{2}$, Doru Alexandru Pleșea ${ }^{3}$ and Irina \\ Albăstroiu ${ }^{4}$ \\ 1) 2) 3)) The Bucharest University of Economic Studies, Bucharest, Romania \\ E-mail: cristian.onete@com.ase.ro; E-mail: sandra.chita@yahoo.com; \\ E-mail: pleseadoru@gmail.com; E-mail : irina.albastroiu@com.ase.ro
}

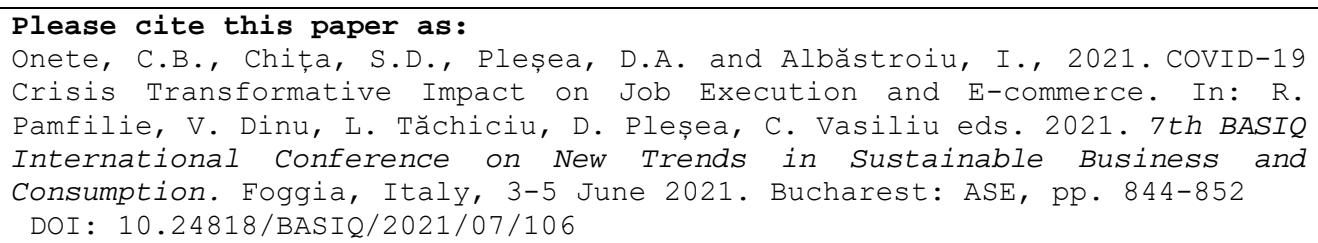

\begin{abstract}
The shock created by the pandemic of COVID -19 forced people to question the way they work, how they spend their free time and what are their priorities. People have turned to digital more than ever, sometimes being the only way to communicate during lockdown or to do a certain activity. Perceptions of the population are changed. The supply and demand are in a continuous transformation. Even though people are generally forced to stay at home because of restrictions, they are more connected than they were before. The present study is highlighting the correlations between transformations that took place on a professional level for people and changes in the usage of social media and electronic commerce. This paper uses a qualitative study based on structured interviews. The key informants are people who suffered modifications in the way they work compared to how it was before the pandemic (they were forced to take a leave, they switched to work from home or to a hybrid format). The purpose of our research is to see how our interviewees' professional life has changed during pandemic and what is the impact on the way they now use social media and e-commerce. The findings of our research show that people developed a tendency to use social media differently depending on their new needs during this period. Also, the average time spent on social media is decreasing. An original point addressed in our paper is the usage of electronic commerce as a hobby, without buying. Recommendations were subsequently made for e-businesses and for professionals.
\end{abstract}

\section{Keywords}

COVID-19 pandemic, social media, electronic commerce, work from home, layoff

DOI: $10.24818 / B A S I Q / 2021 / 07 / 106$

\section{Introduction}

The purpose of this research paper is to see how the habits of people have changed depending on what is happening in the country where they work, depending on what has happened with their job and how this impacted the way they use social media and e-commerce. We have interviewed people from Romania, France and Spain, therefore it is important to understand the context of each of these countries.

The emergence of the pandemic caused by COVID-19 caused a disturbance, both at the level of the European Union and globally, having very important consequences at the economic but also social level. It is estimated that in Romania production will not return to the levels it had before the crisis before the end of 2022. The loss of workplaces and the growth of unemployment have put a lot of pressure on European people and their means of subsistence. However, the economic impact has not been the same at the level of all the countries of the European Union and this variability is also present 
regarding the recovery policies. This lack of uniformity reflects the way in which the virus has been spread, how strict public health measures have been, but also the sectoral composition of each economy and the way in which responses were organized by political institutions (Turcu, 2020).

Since the end of March 2021, in Romania additional measures were adopted by the authorities to prevent the virus from spreading. In some localities where the infection rate is high in the last 14 days, the free movement of people is restricted, until 8 p.m. on Friday, Saturday and Sunday. In some areas, people can go out only until $20 \mathrm{pm}$ even during week (Stirioficiale.ro, 2021).

When it comes to Catalonia, even though the rate of infected people has stabilized, mobility restrictions are maintained. People cannot get out of their house between $10 \mathrm{pm}$ and $6 \mathrm{am}$, shops and malls are open only at $30 \%$ of their capacity, parks and gardens are closed after $8 \mathrm{pm}$ and other facilities as gyms do not function at their maximum capacity. Remote work is advised by the authorities if the companies are able to implement it (Doherty, 2021).

In France, people have a curfew and they need to be home between $19 \mathrm{pm}$ and 6 am and also there is a lockdown, going out is not allowed for long distances, bigger than $10 \mathrm{~km}$ away from the house and some businesses are closed, especially the ones considered to be as non-essential (La Redaction, 2021).

The crisis has generated a huge digital transformation, never seen before and we have witnessed the increase in e-commerce sectors. Even though we are going through a downturn in the economy, COVID-19 has caused a shock in online shopping (UNCTAD, 2021). According to Deloitte, the new habits of people generated by the health crisis could be sustainable and we could adhere to them after the pandemic. Trading conditions between companies but also between companies and consumers have undergone strong changes. All the things that have to do with the way we are currently working or how we run our errands are changing and the purpose of technology is being revolutionized. The changes in the e-commerce could be explained by the fact that shopping in the streets is no longer possible in some areas while in others it is restricted, shops do not work at full capacity. Also, preferences of people are changing, part of this being the desire to keep safe.

Social media as a key role in our society, especially in times of crisis. According to Research by Global WebIndex, as presented by Smart Insights, " $53.6 \%$ of the world's population uses social media. The average daily usage is 2 hours and 25 minutes" (Chaffey, 2021). People have been using social media to stay in contact with each other and a lot of their activities went to online since they couldn't go out as much as they did before, so they had to find new ways of entertainment: "close to half a billion new social users (...) social media, ecommerce, streaming content, and video games all seeing significant growth in the past 12 months" (Kemp, 2021). According to Statista, 25\% of the respondents to a study have purchased clothing online because of the COVID-19 pandemic (Statista, 2021).

\section{Review of the scientific literature}

The changes in the economy will have a major impact on the way organizations plan and organize work, on the type of occupations we will encounter in our professional lives as well as how people will perceive the new "normal". For example, the hospitality industry was one of the most affected ones since the beginning of the pandemic and has suffered many transformations. And while the layoff was necessary for the companies, it has a negative impact on employees, already stressed by the virus. Employers should be taking into consideration a supporting system for their teams (Tu, 2021). For certain categories of people as the ones having routine intensive occupations, the consequence of layoff is harder and it is more difficult to find a new job (Acosta-Prado, et al., 2020; Blien, et al., 2021). Other categories of people have positive perceptions on the transformations of the world, for example students in the field of economic studies, in Romania are open to the recent technological progress in IoT and they are willing to integrate them in their careers (Nemțeanu and Dabija, 2020; Albăstroiu, 2021).

The demand as well as the supply of occupations will be affected according to the transformations of each sector, it is what a study calls "macro changes", while the changes linked with perceptions of occupations are "micro changes" (Krameran and Kramer, 2020). Another topic discussed in the same study is linked to work from home, a very important topic during pandemic. As mentioned by Kramer and Kramer, many people were forced to start working from home, even those who had no experience with this, the teachers for example. The new generations of students have grown up in a digital 
environment and they were ready for online studies (Onete, et al., 2020). At the same time, work from home or learning from home were not arrangements desires by everybody. Of course, there were also people already used to work from home, having different working arrangements: one day per week or per month from home or each time it was needed.

As already mentioned, the COVID-19 crisis has induced multiple disruptions about the way we work, meaning for example when or where. Also, working from home has made it mandatory to use digital technologies to be connected with coworkers. But this has some limitations for some industries. For example, a study shows that for the hospitality industries there is a need to put in place specific policies so that people working for the enterprise will know the rules when it comes to connectivity for example as well as availability. Another issue would be that there is no explicit boundary anymore between work and nonwork, a consequence of the pandemic that puts pressure on employees (Chadee, et al., 2021).

Businesses that allowed it shifted to work from home. Even though some activities couldn't switch to online, they became more prosperous of those which could not because of the type of activity, have known an increase. More and more people needed them and they transformed from something special to something usual, essential for safety. This is the case for home deliveries, even though, as showed by a research, the people who were being part of populations with less access to deliveries did not know a major change in their situation and inequalities increased (Figliozzi and Unnikrishnan, 2021). Sheth (2020) has concluded that three managerial implications could be remembered from this crisis when it comes to the behavior of customers. They had to adapt, therefore, to improvise but this was also the case for companies. Management teams were not able to implement change very fast because of their formal systems. Unfortunately for them, because of their formal systems cannot implement change very fast. Another implication is the balance that should exist between demand and supply. In the beginning of the COVID-19 crisis, people were buying certain categories of products making stocks because they couldn't make forecasts about what was coming next. In the future, we need to encourage online orders and prepare them after the customers expressed their wishes to be delivered. The third consequence is that consumers might continue using digital tools post pandemic depending on the influence they had on their life. In the same time, research shows that the pandemic represents a turning point in people's life. Sustainable consumption as well as increased interest for environmental subjects are part of the change (Severo, et al., 2021).

When it comes to social media, studies show that it has positive and negative aspects during this period. A negative thing would be that some people took measures that do not have a scientific proof, for example eating specific things during pandemic (Cato, et al., 2021). Also, the behaviors of different social media users are similar during the COVID-19 crisis because they are all in survival mode. Before this crisis, shares on social media were associated more with negative feelings in others while the lockdown made people share the same feelings (Kaya, 2020). Social media used for big periods of time has negative consequences as well as implications. It is difficult to say if the excessive usage of social media during pandemic will be considered as chapter and it will go or if it will become addictive and there will be consequences on the mental health of people as well (Singh, et al., 2020).

\section{Research methodology}

Our research paper analyzes how the occupational status of people has changed because of COVID19. We also examine what are the tendencies when it comes to the professional framework (changes in the activity to suit the new needs of the economy, work from home, remote work etc.). Another axis of this paper is linked to how people are using social media during pandemic as well as electronic commerce. The purpose is to observe the situations that people had to face in their professional life and how this impacted the way they usage social media and e-commerce. We constructed our research using a qualitative method and summarizing findings from one-to-one interviews with 11 people working and living in three countries of the European Union, with a different evolution when it comes to pandemic: Romania, Spain and France. All the people are currently working, activating in different fields and performing their job in different ways in this current situation. We used a structured interview which has first been distributed via e-mail to all participants and we have also scheduled either face to face interviews when the restrictions allowed it or calls via WhatsApp. People were willing to share their experiences even though some of them had to face challenging times because of the unexpected 
crisis. The virus is not only affecting people's safety and the health system, but also is provoking a financial and social crisis.

The hypotheses of our research are the following:

- regardless of the field in which they work, people have undergone major transformations in their professional life

- considering their current needs, which can be classified into two categories: financial (need to find a new occupation) and for mental health and well-being, people have turned more to social networks and changed the way they use them

-e-commerce is more like a hobby than a need

This paper is bringing to light a less explored subject, the one of e-commerce without actually buying and also there is a process of deepening what are the new trends of social media, a field in a continuous transformation. Recommendations are made based on what has been observed during the interviews.

\section{Results and discussion}

A total of 11 interviews were conducted in April 2021. Key information about the interviewed people is summarized by category in the Table no.1.

Table no.1: Key information about the interviewed people

\begin{tabular}{|c|c|c|c|c|c|}
\hline No. & $\begin{array}{l}\text { City where } \\
\text { currently } \\
\text { living/ city } \\
\text { where the } \\
\text { job is } \\
\text { normally } \\
\text { based }\end{array}$ & Occupation & $\begin{array}{l}\text { Domain of the } \\
\text { company }\end{array}$ & The main tasks & $\begin{array}{c}\text { Situation of the } \\
\text { job during } \\
\text { pandemic }\end{array}$ \\
\hline 1 & Paris & $\begin{array}{l}\text { Business } \\
\text { Analyst }\end{array}$ & Insurance & $\begin{array}{l}\text { Managing and } \\
\text { implementing } \\
\text { health projects }\end{array}$ & $\begin{array}{l}\text { Work can be } \\
\text { done from } \\
\text { everywhere } \\
\text { during pandemic } \\
\text { Promotion might } \\
\text { be possible in the } \\
\text { future }\end{array}$ \\
\hline 2 & Paris & Consultant & Consulting & $\begin{array}{l}\text { Managing project, } \\
\text { decision making } \\
\text { guidance, } \\
\text { recommendations, } \\
\text { interviews, change } \\
\text { management }\end{array}$ & $\begin{array}{l}\text { Change of } \\
\text { project during } \\
\text { pandemic } \\
\text { Started working } \\
\text { remote }(100 \%)\end{array}$ \\
\hline 3 & Paris & Consultant & $\begin{array}{l}\text { Management } \\
\text { and } \\
\text { organizational } \\
\text { consulting }\end{array}$ & $\begin{array}{l}\text { Monitoring KPI } \\
\text { Designing } \\
\text { security strategy } \\
\text { through digital } \\
\text { applications } \\
\text { Writing } \\
\text { administrative } \\
\text { notes } \\
\text { Change } \\
\text { management }\end{array}$ & $\begin{array}{l}\text { Work from home } \\
2-3 \text { days/week } \\
\text { because the client } \\
\text { requires physical } \\
\text { presence for } \\
\text { some meetings } \\
\text { During } \\
\text { pandemic: the } \\
\text { same activity, } \\
\text { without getting a } \\
\text { promotion. }\end{array}$ \\
\hline
\end{tabular}




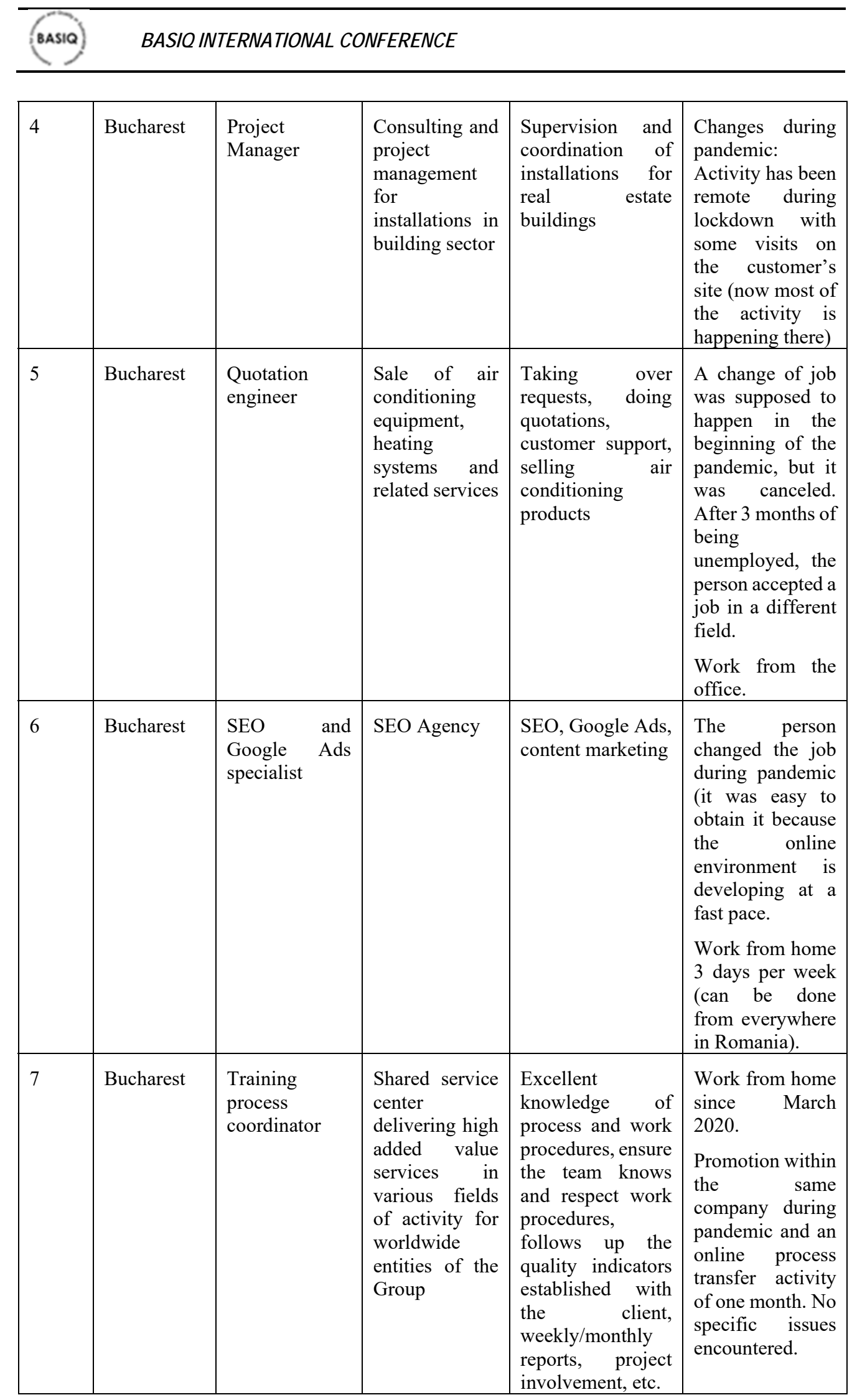




\begin{tabular}{|c|c|c|c|c|c|}
\hline & & \multicolumn{4}{|c|}{ New Trends in Sustainable Business and Consumption } \\
\hline 8 & Barcelona & $\begin{array}{l}\text { Window } \\
\text { dresser }\end{array}$ & Retail & $\begin{array}{l}\text { Preparing the } \\
\text { image of the store, } \\
\text { showcases, } \\
\text { mannequins and } \\
\text { products by } \\
\text { season } \\
\text { collections. }\end{array}$ & $\begin{array}{l}\text { Temporary } \\
\text { layoff called } \\
\text { ERTE } \\
\text { (Expediente de } \\
\text { Regulación de } \\
\text { Empleo) because } \\
\text { the store was } \\
\text { closed for } 2 \\
\text { months in the } \\
\text { beginning of the } \\
\text { pandemic. This } \\
\text { happened } 2 \text { more } \\
\text { times during this } \\
\text { year. } \\
\text { No changes, } \\
\text { physical } \\
\text { presence at work } \\
\text { is mandatory } \\
\text { when the store is } \\
\text { open and there } \\
\text { were restrictions, } \\
\text { only } 30 \% \text { of the } \\
\text { store was open. }\end{array}$ \\
\hline 9 & Barcelona & Retail & Retail & $\begin{array}{l}\text { Customer service, } \\
\text { stock } \\
\text { management, } \\
\text { cashier, etc. }\end{array}$ & $\begin{array}{l}\text { After the first } \\
\text { lockdown the } \\
\text { company } \\
\text { realized they } \\
\text { needed an online } \\
\text { store. The store } \\
\text { was reopened } \\
\text { and then closed } \\
\text { again, but } \\
\text { meanwhile the } \\
\text { online one was } \\
\text { ready. When the } \\
\text { store was closed, } \\
\text { they were } \\
\text { working to } \\
\text { prepare the } \\
\text { online orders. }\end{array}$ \\
\hline 10 & Barcelona & $\begin{array}{l}\text { Visual } \\
\text { Merchandiser }\end{array}$ & Retail & $\begin{array}{l}\text { Presentation and } \\
\text { commercialization }\end{array}$ & $\begin{array}{l}\text { Layoff (ERTE) } \\
\text { for } 5 \text { months (in } \\
\text { different periods } \\
\text { of time). } \\
\text { Physical } \\
\text { presence } \\
\text { mandatory when } \\
\text { the store is open. }\end{array}$ \\
\hline 11 & Barcelona & $\begin{array}{l}\text { Visual } \\
\text { Merchandiser }\end{array}$ & Retail & $\begin{array}{l}\text { Presentation and } \\
\text { commercialization }\end{array}$ & $\begin{array}{l}\text { Just moved to } \\
\text { Barcelona from } \\
\text { Bucharest in } \\
\text { February, before }\end{array}$ \\
\hline
\end{tabular}




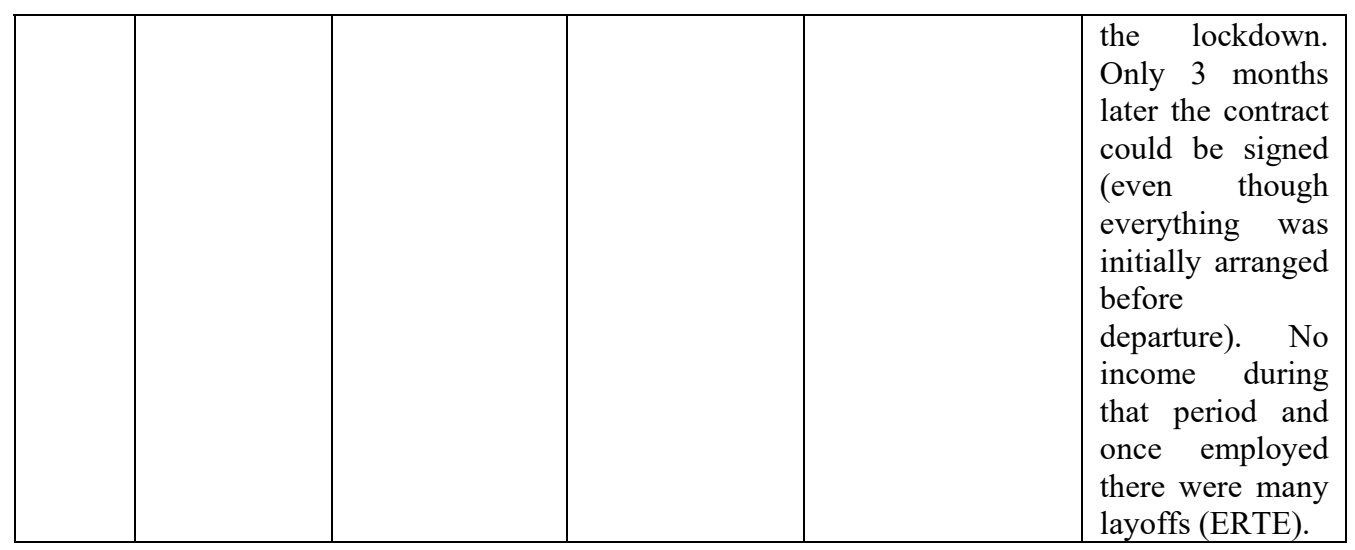

We can see in Table no. 1 that people went through very different situations based on the type of work they have. For those having jobs that can easily be done from home or remote, they could easily change their job or get a promotion in their current company during pandemic. When it comes to jobs that cannot be done remotely, the situation was different. We have interviewed engineers as well as people working in retail. For them, pandemic came when they were between jobs and this had a negative impact, being translated in a period of being unemployed. Also, people stopped working during certain periods of time because of rules imposed by the authorities. An important aspect to be underlined here is that some of the businesses which were not prepared for the online environment during pandemic took actions and they were able to help their employees by changing their activities to be more suitable for the online environment when the activity in the headquarters was stopped.

When it comes to social media, the first lockdown made people use them more because they needed to keep in contact with their families and friends. New apps were installed as Housparty for this purpose but meanwhile Twitter and LinkedIn were used to stay informed, keep in touch with professional connections and to keep an open eye on the job market. Their usage was increased even though the majority of the people we interviewed are not using them for their current job. However, when the first shock has passed, people realized they spend too much time in front of screens and have reduced it. At the same time, social media was less used by those who were sharing and following for trips, concerts and other type of events. Some of the disadvantages of social media perceived by the interviewed people are: more dependent on devices, cannot tell what is the truth, data protection, usurpation of identity, loss of self-esteem, mass manipulation.

All the interviewed people have reduced the usage of their social media as well as the way in which they are using them, having a precise purpose for each platform. At the same time, they have increased the usage of online stores as a hobby in order to keep updated with new tendencies, to check for sales or stocks. Most of our respondents are doing so as a way of spending free time or as a hobby. Some are doing it because it is helpful for their professional life and the other because it is a passion. The duration of this activity goes from 15-30 minutes daily to 10 hours per week, without buying. At the same time, this habit helps them take better decisions when they actually decide to place an order. For some people, most of their life went digital: professional life, shopping, courses, sports, communication, social events, meditation.

\section{Conclusions}

It has been more than a year since the COVID-19 crisis has completely disrupted the way we were living and working. A lot of measures are put in place to keep people safe. These measures impact the way we conduct our activities. We can see many transformations take place, especially in the way of working. Our research shows that jobs that can be done remotely are more likely to survive to a crisis like this one. People having digital occupations are less stressed, they can easily find new jobs and they have hopes for promotions. People who depend on a physical activity or direct contact with their customers in their daily jobs are more at risk of pressure and stress. They might be asked to stop their professional activity every time the sanitary situation gets worse. Also, the transformations in the 
professional life impact the usage of social media. The necessity to be correctly informed is increasing. People need to communicate and some of them to seek employment. At the same time they realize excessive usage of social media is not good and they start preferring human interaction and invest more time in themselves and in online stores, the new "social media". Our hypotheses are therefore true even though we have to mention the purposes, type of transformations and their time frame are different for each individual. There are also some limitations of this study. We would like to mention the limited number of respondents as well as the particularity of each country. An additional quantitative research by country is to be taken into consideration in the future. We recommend online stores to implement some bonus points used as vouchers for their customers depending on how much time they have spent on their website. For professionals we recommend they take advantages of less fortunate situations to learn and obtain new skills. In the future companies as well as people should be ready to go digital whenever a situation will demand it.

\section{References}

Acosta-Prado, J.C., Sandoval-Reyes, J.G. and Sanchís-Pedregosa, C., 2020. Job Demands and Recovery Experience: The Mediation Role of Heavy Work Investment. Amfiteatru Economic, 22(Special Issue No. 14), pp.1206-1226.

Albăstroiu, I., 2021. Challenges of IoT Technologies for Businesses and Consumers. Amfiteatru Economic, 23(57), pp.321-323.

Blien, U., Dauth, W. and Roth, D.H.W., 2021. Occupational routine intensity and the costs of job loss: evidence from mass layoffs. Labour Economics, 68, Article number: 101953.

Cato, S., Iida, T., Ishida, K., Ito, A., Katsumata, H., McElwain, K.M. and Shoji, M., 2021. The bright and dark sides of social media usage during the COVID-19 pandemic: Survey evidence from Japan. International Journal of Disaster Risk Reduction, 54, Article number: 102034.

Chaffey, 2021. Global social media statistics research summary [updated 2021], [online] Smart Insights. Available at: <https:/www.smartinsights.com/social-media-marketing/social-mediastrategy/new-global-social-media-research/> [Accessed 22 April 2021].

Deloitte, 2021. COVID-19 will permanently change e-commerce in Denmark. [pdf] Available at: $<$ https:/www2.deloitte.com/content/dam/Deloitte/dk/Documents/strategy/e-commerce-covid-19onepage.pdf $>$ [Accessed 20 April 2021].

Doherty, L., 2021. What are the latest Covid-19 measures in Catalonia? [online] Available at: https://www.catalannews.com/covid-19/item/what-are-the-latest-covid-19-measures-in-catalonia> [Accessed 20 April 2021].

Figliozzi, M. and Unnikrishnan, A., 2021. Home-deliveries before-during COVID-19 lockdown: Accessibility, environmental justice, equity, and policy implications. Transportation Research Part D: Transport and Environment, 93, Article number: 102760.

Kaya, T., 2020. The changes in the effects of social media use of Cypriots due to COVID-19 pandemic. Technology in Society, 63, Article number: 101380.

Kemp, 2021. Digital 2021: Global Overview Report, [online] DataReportal - Global Digital Insights. Available at: $<$ https://datareportal.com/reports/digital-2021-global-overview-report $>$ [Accessed 22 April 2021].

Kramer, A. and Kramer, K.Z., 2020. The potential impact of the Covid-19 pandemic on occupational status, work from home, and occupational mobility. Journal of Vocational Behavior, 119, Article number: 103442 .

La Rédaction, 2021. Confinement en France : efficace mais prolongé? Les règles, [online] Available at: <https://www.linternaute.com/actualite/guide-vie-quotidienne/2489337-confinement-enfrance-est-il-efficace-le-rappel-des-regles/> [Accessed 20 April 2021].

Nemțeanu, M.S. and Dabija, D.C., 2020. The Influence of Heavy Work Investment on Job Satisfaction and Turnover Intention in Romania. Amfiteatru Economic, 22(Special Issue 14), pp.993-1013. 
Onete, B.C., Budz, S., Vargas, V.M. and Chița, S.D., 2020. The Relationship Between E-Learning and Sustainability. The Blog as a Future E-Learning Tool. In: R. Pamfilie, V. Dinu, L. Tăchiciu, D. Pleșea, C. Vasiliu eds. 6th BASIQ International Conference on New Trends in Sustainable Business and Consumption. Messina, Italy, 4-6 June 2020. Bucharest: ASE, pp. 675-682

Severo, E.A., De Guimarães, J.C.F. and Dellarmelin, M.L., 2021. Impact of the COVID-19 pandemic on environmental awareness, sustainable consumption and social responsibility: Evidence from generations in Brazil and Portugal. Journal of Cleaner Production, 286, Article number: 124947.

Sheth, J., 2020. Impact of Covid-19 on consumer behavior: Will the old habits return or die? Journal of Business Research, 117, pp.280-283.

Singh, S., Dixit, A. and Joshi, G., 2020. "Is compulsive social media use amid COVID-19 pandemic addictive behavior or coping mechanism? Asian Journal of Psychiatry, 54, Article number: 102290.

Statista, 2021. Online shopping due to the COVID-19 pandemic 2020, [online] Statista. Available at: $<$ https://www.statista.com/statistics/1107859/shifting-to-online-purchases-because-of-the-covid19-pandemic-by-category/> [Accessed 22 April 2021].

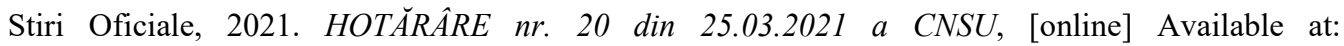
$<$ https://stirioficiale.ro/hotarari/hotarare-nr-20-din-25-03-2021-a-cnsu> [Accessed 20 April 2021].

Tu, Y., Li, D. and Wang, H.-J., 2021. COVID-19-induced layoff, survivors' COVID-19-related stress and performance in hospitality industry: The moderating role of social support. International Journal of Hospitality Management, 95, Article number: 102912.

Turcu, S., 2020. Previziunile economice din toamna anului 2020: România - PIB-ul va scădea cu 5,2 \% în 2020 și va crește cu aproximativ 3,3\% in 2021, respectiv cu 3,8\% în 2022, [online] România - European Commission. Available at: $<$ https://ec.europa.eu/romania/news/20201105_previziunile_economice_toamna_romania_ro> [Accessed 18 April 2021].

UNCTAD, 2021. How COVID-19 triggered the digital and e-commerce turning point | UNCTAD, [online] Available at: <https://unctad.org/news/how-covid-19-triggered-digital-and-e-commerceturning-point $>$ [Accessed 20 April 2021]. 